\title{
Correction to: Application of remote sensing techniques toward the role of traditional water bodies with respect to vegetation conditions
}

\author{
Ram Avtar ${ }^{1,2} \cdot$ Srikantha Herath $^{1} \cdot$ Osamu Saito ${ }^{1}$. Weena Gera ${ }^{1,5} \cdot$ Gulab Singh $^{3}$. \\ Binaya Mishra ${ }^{1} \cdot$ Kazuhiko Takeuchi $^{1,4}$
}

Published online: 25 October 2019

(c) Springer Nature B.V. 2019

\section{Correction to: Environ Dev Sustain https://doi.org/10.1007/s10668-013-9507-4}

Co-author, Weena Gera's institutional affiliation at the time of publication also includes the University of the Philippines Cebu, Cebu, Philippines.

Publisher's Note Springer Nature remains neutral with regard to jurisdictional claims in published maps and institutional affiliations.

The original article can be found online at https://doi.org/10.1007/s10668-013-9507-4.

Ram Avtar

avtar@unu.edu

1 United Nations University, Institute for Sustainability and Peace (UNU-ISP), Tokyo, Japan

2 Research Institute for Global Change, Japan Agency for Marine-Earth Science and Technology, Yokohama, Japan

3 Graduate School of Science and Technology, Niigata University, Niigata, Japan

4 Integrated Research System for Sustainability Science, University of Tokyo, Tokyo, Japan

5 University of the Philippines Cebu, Cebu, Philippines 